\title{
PENEGAKAN HUKUM TERHADAP TINDAK PIDANA PELANGGARAN IZIN TINGGAL BAGI WARGA NEGARA ASING
}

\author{
Ketut Yunda Anastesia, Kementerian Hukum dan Hak Asasi Manusia, \\ E-mail: yundaanastesia@gmail.com
}

\begin{abstract}
Abstrak
Tujuan dari penelitian ini adalah untuk mengetahui dan menganalisa proses penegakan hukum terhadap tindak pidana pelanggaran izin tinggal bagi Warga Negara Asing dan hambatan dalam pengawasan dan penegakan hukum terhadap tindak pidana pelanggaran izin tinggal bagi Warga Negara Asing di Kantor Kantor Imigrasi Kelas I Khusus Tempat Pemeriksaan Imigrasi (TPI) Ngurah Rai, Bali. Jenis penelitian yang digunakan adalah penelitian empirik, dimana peneliti melakukan studi tekstual, yakni menganalisis secara kritikal terhadap pasal-pasal dalam peraturan perundang-undangan, dan melakukan studi empirik dalam hal melihat proses penegakan hukum terhadap tindak pidana penyalahgunaan izin tinggal menurut peraturan Undang-Undang Nomor 6 Tahun 2011 tentang Keimigrasian. Hasil Penelitian menunjukan pertama, proses penegakan hukum terhadap tindak pidana pelanggaran izin tinggal bagi Warga Negara Asing di Kantor Imigrasi Kelas I Khusus TPI Ngurah Rai, Bali yakni dengan Tindakan Projustisia dan Tindakan Administratif Keimigrasian berupa deportasi. Dalam proses penahan warga negara asing sebelum dilakukan tindakan deportasi diberikan hak-hak sesuai dengan kebutuhan pokok sehari-harinya. Kedua, hambatan dalam pengawasan dan penegakan hukum terhadap tindak pidana pelanggaran izin tinggal bagi Warga Negara Asing di Kantor Imigrasi Kelas I Khusus TPI Ngurah Rai, Bali yakni, faktor pendukung yang mempengaruhi pengawasan dan penegakkan hukum terhadap Tindak Pidana pelanggaran Izin Tinggal bagi warga negara asing: Adanya TIMPORA (Tim Pengawasan Orang Asing); Adanya APAPOA (Aplikasi Pelaporan Orang Asing); SSO (Single Sign On). Faktor penghambat yang mempengaruhi pengawasan dan penegakkan hukum terhadap Tindak Pidana pelanggaran Izin Tinggal bagi warga negara asing: SDM (Sumber Daya Manusia); Fasilitas Penunjang; Waktu yang relatif lama dalam menyelesaikan berkas perkara.
\end{abstract}

Keywords: Cultivation Rights, Investment, Decisions of the Constitutional Court

\begin{abstract}
The purpose of this research is to find out and analyze the process of law enforcement against violations of residence permit violations for Foreign Citizens and barriers to supervision and law enforcement against criminal violations of residence permits for Foreign Citizens at the Immigration Class I Office of Special Immigration Examination Offices (TPI) Ngurah Rai, Bali. The type of research used is empirical research, in which researchers conduct textual studies, namely critically analyzing the articles in the legislation, and conducting empirical studies in terms of seeing the process of law enforcement against criminal acts of abuse of residence permit according to the provisions of the Law Number 6 of 2011 concerning Immigration. The research results show first, the process of law enforcement against criminal violations of residence permits for Foreign Citizens in the Special Class I Immigration Office of TPI Ngurah Rai, Bali, namely the Pro justification Act and the Immigration Administrative Act in the form of deportation. In the process of detaining foreign citizens before deportation measures are given rights in accordance with their basic daily needs. Second, obstacles in supervision and law enforcement against criminal violations of residence permits for Foreign Citizens in the Special Class I Immigration Office of TPI Ngurah Rai, Bali namely, supporting factors that influence the supervision and law enforcement of Criminal Acts violating Stay Permits for foreign nationals: The existence of TIMPORA (Foreigner Monitoring Team); APAPOA (Alien Reporting Application); SSO (Single Sign On). Inhibiting factors that influence supervision and law enforcement of Criminal Acts violating Stay Permits for foreign nationals: HR (Human Resources); Supporting Facilities; A relatively long time in completing the case file.
\end{abstract}


Kata kunci: Hak Guna Usaha, Penanaman Modal, Putusan Mahkahmah Konstitusi

\section{Pendahuluan}

\subsection{Latar Belakang Masalah}

Fokus permasalahan dalam latar belakang ini, berkaitan dengan pelanggaran Izin tinggal bagi orang asing di berdasarkan Kantor Imigrasi Kelas I Khusus Tempat Pemeriksaan Imigrasi (TPI) Ngurah Rai, Bali. Orang asing yang memasuki wilayah Indonesia harus memiliki dokumen perjalanan yang lengkap dan valid. Dokumen perjalanan menyertakannya paspor, visa dan izin tinggal. Penjelasan tentang paspor, visa dan izin tinggal dapat dijumpai dalam Pasal 24, Pasal 8 ayat (2), Pasal 48 UndangUndang Republik Indonesia Nomor 6 Tahun 2011 tentang Keimigrasian. Dalam Pasal 34 Undang-Undang Republik Indonesia Nomor 6 Tahun 2011 tentang Keimigrasian menyatakan adapun jenis visa yaitu, visa diplomatik, visa dinas, visa kunjungan dan visa tinggal terbatas. Masalah yang sering muncul dari masalah dokumen perjalanan adalah masalah pelanggaran terhadap izin tinggal yang tidak sesuai dengan tujuan pemberian izin tinggal, penjelasan lebih lanjut tercantum dalam Pasal 48 ayat 2 Undang-Undang Republik Indonesia Nomor 6 Tahun 2011 tentang Keimigrasian.

Jumlah pelanggaran keimigrasian yang dikaitakan dengan ketentuan Undang-Undang Republik Indonesia Nomor 6 Tahun 2011 tentang Keimigrasian yang memuat Bab XI tentang ketentuan pidana dalam Pasal 113-136, dapat dilihat dalam tabel di bawah ini:

Tabel 1

Jumlah Pelanggaran Keimigrasian bertalian dengan Undang-Undang Keimigrasian

\begin{tabular}{|l|l|l|}
\hline No & $\begin{array}{l}\text { Undang-Undang Republik Indonesia Nomor 6 Tahun } \\
\text { 2011 tentang Keimigrasian }\end{array}$ & Jumlah Kasus \\
\hline 1. & Pasal 75 & 12 \\
\hline 2. & Pasal 122 ayat a & 13 \\
\hline 3. & Pasal 124 & 40 \\
\hline
\end{tabular}

Sumber: Kantor Imigrasi Kelas I Khusus TPI Ngurah Rai, Bali

Tabel yang telah tertera di atas dapat dipahami bahwa pada dalam Pasal 75 jumlah pelanggaran imigrasi sebanyak 12, dan di lanjutkan dengan Pasal 122 ayat a dengan jumlah kasus sebanyak 13, dan selanutnya pada Pasal 124 jumlah kasus sebanyak 40. Perbandingan diantara tiga pasal maka dapat dilihat yang paling tinggi pada Pasal 124 dan yang paling rendah pada Pasal 75.

Adapun pokok kajian yang ingin dibahas dalam penelitian ini, yaitu; pertama, bagaimana proses penegakan hukum terhadap tindak pidana pelanggaran izin tinggal bagi Warga Negara Asing di Kantor Imigrasi Kelas I Khusus TPI Ngurah Rai, Bali. Kedua, apa hambatan dalam pengawasan dan penegakan hukum terhadap tindak pidana pelanggaran izin tinggal bagi Warga Negara Asing di Kantor Imigrasi Kelas I Khusus TPI Ngurah Rai, Bali. Adapun beberapa jurnal yang mimiliki tema serupa mengenai penegakan hukum terhadap tindak pidana pelanggaran izin tinggal bagi Warga Negara Asing adalah dengan judul Penegakan Hukum Terhadap Warga 
Negara Asing Yang Melakukan Tindak Pidana Pemalsuan Dokumen Perjalanan (Studi Di Kantor Imigrasi Kelas I Khusus Ngurah Rai) yang dimuat dalam jurnal Kertha Wicara: Journal Ilmu Hukum Udayana, Peran Kantor Imigrasi Kelas I Denpasar Dalam Mencegah Penyalahgunaan Bebas Visa Kunjungan Bagi Orang Asing Di Kota Denpasar yang dimuat dalam jurnal Kertha Negara: Jurnal Ilmu Hukum Udayana. Yang membedakan dengan jurnal ini adalah dalam jurnal ini mencoba menjelaskan penegakan hukum terhadap tindak pidana pelanggaran izin tinggal bagi Warga Negara Asing (Studi Kasus di Kantor Imigrasi Kelas I Khusus TPI Ngurah Rai, Bali).

\subsection{Rumusan Masalah}

Berdasarkan pada uraian latar belakang masalah sebelumnya, maka rumusan masalah yang diangkat adalah bagaimana proses penegakan hukum terhadap tindak pidana pelanggaran izin tinggal bagi Warga Negara Asing di Kantor Imigrasi Kelas I Khusus TPI Ngurah Rai, Bali? Dan apa hambatan dalam pengawasan dan penegakan hukum terhadap tindak pidana pelanggaran izin tinggal bagi Warga Negara Asing di Kantor Imigrasi Kelas I Khusus TPI Ngurah Rai, Bali.

\subsection{Tujuan Penelitian}

Tujuan dari penelitian ini adalah untuk mengetahui dan menganalisa proses penegakan hukum terhadap tindak pidana pelanggaran izin tinggal bagi Warga Negara Asing dan hambatan dalam pengawasan dan penegakan hukum terhadap tindak pidana pelanggaran izin tinggal bagi Warga Negara Asing di Kantor Imigrasi Kelas I Khusus TPI Ngurah.

\section{Metode Penelitian}

Penelitian ini dikaji menggunakan penelitian normatif ${ }^{1}$. Penelitian normatif merupakan salah satu model pendekatan dalam penelitian hukum dalam konteks pelaksanaan atau penerapan hukum di dalam masyarakat ${ }^{2}$. Adapun pendekatan penelitian adalah analisis konsep (The Analictical and Conseptual Approach) ${ }^{3}$. Selain itu data yang digunakan yaitu pertama, primer ${ }^{4}$ data sekunder. Selanjuntnya teknik

${ }^{1}$ Disemadi, Hari Sutra; Prananingtyas, Paramita. Perlindungan Hukum Terhadap Nasabah Perbankan Pengguna CRM (Cash Recycling Machine). Jurnal Magister Hukum Udayana (Udayana Master Law Journal, [S.1.], v. $\quad 8, \quad$ n. $3, \quad$ p. 286402,https://doi.org/10.24843/JMHU.2019.v08.i03.p07.

2 Salim, H.S., \& Nurbani, E.S. Penerapan Teori Hukum Pada Penelitian Tesis Dan Disertasi. Jakarta : PT RajaGrafindo Persada, (2014). h. 22..

${ }^{3}$ Susila, I. N. A. Pengaturan Kawasan Suci Pantai Dalam Penyediaan Sarana Wisata Tirta Di Provinsi Bali. Jurnal Magister Hukum Udayana (Udayana Master Law Journal), 6 no. 4, (2017), 478-488. https:// doi.org/10.24843/JMHU.2017.v06.i04.p06.

4 Dharmawan, N. K. S. Keberadaan Pemegang Saham dalam Rups dengan Sistem Teleconference Terkait Jaringan Bermasalah dalam Perspektif Cyber Law. Jurnal Magister Hukum Udayana (Udayana Master Law Journal), 4 no. 1, (2015).. 190-202. https:// doi.org/10.24843/JMHU.2015.v04.i01.p15. 
pengumpulan penelitian adalah studi kepustakaan, serta teknik analisis bahan hukum dengan menggunakan deskripsi5 ${ }^{5}$, dan argumentasi hukum6.

\section{Hasil Dan Pembahasan}

3.1 Proses Penegakan Hukum terhadap Tindak Pidana Pelanggaran Izin Tinggal bagi Warga Negara Asing di Kantor Imigrasi Kelas I Khusus TPI Ngurah Rai, Bali

Berdasarkan hasil Penelitian pada Kantor Imigrasi Kelas I Khusus TPI Ngurah Rai, Bali, menurut Bapak Beny Septada selaku Kepala Seksi Pengawasan dan Penindakan Keimigrasian, menjelaskan bahwa:

"Dalam penyelesaian kasus tindak pidana penyalahgunaan izin tinggal keimigrasian oleh warga negara asing dilakukan dengan 2 cara yaitu tindakan adminstratif keimigrasian (di luar system peradilan pidana) dan tindakan projustisia (proses peradilan) yang termasuk di dalam Sistem Peradilan Pidana (Criminal Justice System)". ${ }^{7}$

Tindakan-tindakan tersebut diuraikan sebagai berikut:

a. Tindakan Administratif Keimigrasian

Tindakan (administrasi) keimigrasian, yang mengacu pada UndangUndang Nomor 6 Tahun 2011 Tentang Keimigrasian Pasal 1 ayat (31) yaitu sanksi administratif yang ditetapkan Pejabat Imigrasi terhadap orang asing diluar proses peradilan. Pasal 75 ayat (1) Undang-Undang Republik Indonesia Nomor 6 Tahun 2011 tentang Keimigrasian menentukan alasan tindakan (administrasi) keimigrasian bahwa apabila orang asing yang berada di wilayah Indonesia yang melakukan kegiatan berbahaya dan patut diduga membahayakan keamanan dan ketertiban umum atau tidak menghormati atau tidak menaati peraturan perundang-undangan.

Pasal 75 ayat (2) Undang-Undang Republik Indonesia Nomor 6 Tahun 2011 tentang Keimigrasian menentukan tindakan (administrasi) keimigrasian yang dapat berupa:

1) Pencantuman dalam daftar pencegahan atau penangkalan;

2) Pembatasan, perubahan atau pembatalan Izin Tinggal;

3) Larangan untuk berada di satu atau beberapa tempat tertentu di wilayah Indonesia;

4) Keharusan untuk bertempat tinggal di suatu tempat tertentu di wilayah Indonesia;

5) Pengenaan biaya beban; dan / atau

6) Deportasi dari wilayah Indonesia.

${ }^{5}$ Siki, Renhat M. Kajian Karakteristik Bentuk dan Isi Perda Tentang Bendega Jurnal Magister Hukum Udayana (Udayana Master Law Journal), 7 no. 3 (2018), 375-385. https://doi.org/10.24843/JMHU.2018.v07.i03.p08.

${ }^{6}$ Atmaja, G. M. W. Politik Pluralisme Hukum Dalam Pengakuan Kesatuan Masyarakat Hukum Adat Dengan Peraturan Daerah. Disertasi Doktor. PDIH Fakultas Hukum Universitas Brawijaya, Malang, (2012)., h. 17.

7 Beny Septada, Kepala Seksi Pengawasan dan Penindakan Keimigrasian, Wawancara, Ruang Office Imigrasi TPI Ngurah Rai, 14 Februari 2020, pukul 15.00 WITA. 
Kemudian, menurut Muammar Reza selaku Analis Keimigrasian Pertama Bidang Intelijen dan Penindakan Keimigrasian lebih lanjut mengatakan bahwa "selain itu berdasarkan ketentuan perundang-undangan yang ada hampir setiap kasus keimigrasian dapat dikenakan Tindakan Administratif Keimigrasian (Deportasi), hal ini terjadi karena kewenangan yang diberikan oleh Undang-Undang sangat luas dan seperti suatu Pasal karet. Penentuan apakah dikenakan Tindakan Keimigrasian ataukah di proses melalui proses peradilan sepenuhnya ditentukan oleh Pejabat Imigrasi di setiap tingkatan struktur organisasi. Kemudian ketidakjelasan sanksi administratif yang diberlakukan terhadap ancaman yang bukan bersifat administratif terjadi secara meluas dalam hal penegakan hukum keimigrasian", (Wawancara hari Jumat, tanggal 31 Januari 2020, pukul 16.30 WITA, di Ruang Penindakan Keimigrasian Kantor Imigrasi Kelas I Khusus TPI Ngurah Rai).

Berdasarkan hasil Penulisan di Kantor Imigrasi Kelas I Khusus TPI Ngurah Rai, Bali, terhadap penanganan warga negara asing yang melakukan tindak pidana penyalahgunaan izin tinggal keimigrasian, dapat disajikan dalam bentuk tabel jumlah kasus tindak pidana imigrasi yang dilakukan dengan tindakan administratif keimigrasian sebagai berikut:

Tabel 2

Tindakan Administratif Keimigrasian Tahun 2018-2019

\begin{tabular}{|l|l|l|}
\hline No & Tahun & Jumlah Kasus \\
\hline 1 & 2018 & 186 \\
\hline 2 & 2019 & 169 \\
\hline
\end{tabular}

Sumber : Kantor Imigrasi Kelas I Khusus TPI Ngurah Rai, Bali

Berdasarkan data tersebut yang bersumber dari Bidang Intelijen dan Penindakan Keimigrasian, bahwa terhadap kasus tindak pidana keimigrasian yang terjadi antara tahun 2018 sampai dengan tahun 2019, oleh pejabat imigrasi lebih memberikan tindakan secara non justisia. Tindakan yang dilakukan adalah dalam hal ini pendeportasian yang kemudian diberikan tindakan penangkalan terhadap orang asing tersebut untuk tidak masuk ke wilayah Indonesia selama 1 tahun dengan jangka waktu perpanjangan penangkalan maksimal 2 tahun.

Contoh kasus yang pernah terjadi terhadap warga Negara Tiongkok yang bernama Xu Dapeng, Tempat tanggal lahir: Anhul, 5 Agustus 2020, nomor paspor: E22010434 yang diterbitkan pada tanggal 20 Juni 2013 berlaku sampai dengan 19 Juni 2023; Alamat di RRT: Guangzhou, Dong Yayuan 12-1-101, Alamat di Indonesia: Gang BaikBaik No 7 Seminyak.

Ia (Xu Dapeng) diminta keterangannya dalam Berita Acara Pemeriksaan pada tanggal 18 Januari 2020 sehubungan dengan keberadaan, kegiatan, dan izin tinggal. Buktibukti dari Berita Acara Pemeriksaan diperoleh fakta-fakta yakni:

1. Bahwa Xu Dapeng terakhir datang ke Indonesia pada tanggal 6 Desember 2019 melalui Bandara Internasional I Gusti Ngurah Rai menggunakan Visa Exemption atau Bebas Visa Kunjungan (BVK) untuk tujuan liburan di Bali; 
2. Bahwa setelah dilakukan pemeriksaan Xu Dapeng bekerja untuk PT. Kedipan Bintang Ubud sebagai perantara dagang dengan Guangzhou Yucai Wenhua dengan mengambil keuntungan margin bisnis kedua perusahaan tersebut.

Berdasarkan fakta-fakta tersebut diatas maka Tim Bidang Intelijen dan Penindakan Keimigrasian Kantor Imigrasi Kelas I Khusus TPI Ngurah Rai memberikan Tindakan Administrasi Keimigrasian kepada Xu Dapeng berupa Pendeportasian. Namun dalam pelaksanaannya seringkali terkendala terhadap biaya terhadap pemulangan orang asing sehingga banyak orang asing yang menumpuk di Rudenim. Pada saat proses pemulangan orang asing tersebut dilakukan pengawasan keberangkatan oleh petugas Imigrasi sampai ke tempat pemeriksaan Imigrasi, kemudian diberikan tanda penolakan dipaspornya oleh petugas Imigrasi di Tempat Pemeriksaan Imigrasi baik di bandara maupun pelabuhan dan orang asing tersebut dipulangkan.

b. Tindakan Projustisia

Pegawai Imigrasi pada Kantor Imigrasi Kelas I Khusus TPI Ngurah Rai, Bali secara faktual dibagi dalam 2 (dua) jenis kepegawaian yaitu pegawai tata usaha dan pegawai teknis yang disebut pejabat Imigrasi. Pejabat Imigrasi inilah yang dapat berfungsi sebagai penyidik untuk melakukan penyidikan tindak pidana keimigrasian, tetapi tidak semua pejabat Imigrasi dapat disebut penyidik, hanyalah pejabat Imigrasi yang sudah mendapatkan pendidikan di Pusdik Reskrim Polri, Megamendung yang dapat disebut sebagai penyidik.

Dalam pendidikan tersebut, PPNS Imigrasi belajar mengenai proses penyidikan tindak pidana keimigrasian. Tindakan Pro justisia yaitu penanganan suatu tindak pidana keimigrasian melalui proses peradilan, yang termasuk di dalam Sistem Peradilan Pidana. Tindakan secara pro justisia diberikan kepada orang asing yang melakukan tindak pidana atau pelanggaran keimigrasian yang tercantum dalam Undang-Undang Republik Indonesia Nomor 6 Tahun 2011 jo Peraturan Pemerintah Nomor 31 Tahun 2013 tentang Rumah Detensi Imigrasi, dilakukan dengan penyidikan terhadap tersangka dan barang bukti yang berkaitan dengan tindak pidana Imigrasi yang dilakukan, melakukan tindakan pertama di tempat kejadian, melakukan tindakan pengkarantinaan terhadap orang asing, melakukan penggeledahan, penyitaan dan pemeriksaan terhadap tempat, benda-benda, dokumen-dokumen, surat-surat yang berkaitan dengan tindak pidana imigrasi, memanggil para saksi dan tersangka, dengan disertai pembuatan berita acaranya disetiap tindakan hukum yang dilakukan. Warga negara asing apabila kedapatan tertangkap tangan melakukan tindak pidana imigrasi ataupun tindak pidana imigrasi yang berkaitan dengan tindak pidana lainnya maka penyidik dapat secara langsung melakukan tindakan seperti yang diatur dalam Pasal 5 ayat (1) huruf b KUHAP yaitu:

1). Pengangkapan, larangan meninggalkan tempat, penggeledahan dan penyitaan;

2). Pemeriksaan dan penyitaan surat;

3). Mengambil sidik jari dan memotret seseorang;

4). Membawa dan menghadapkan seorang pada penyidik.

Tindakan Projustisia ini dilaksanakan oleh pejabat Imigrasi khususnya Penyidik Pegawai Negeri Sipil (PPNS) Imigrasi. Dimana diberi wewenang oleh UndangUndang untuk melakukan penegakan hukum keimigrasian terhadap pelanggaran 
tindak pidana keimigrasian. PPNS Imigrasi melakukan kordinasi dengan penyidik polri dalam hal pemberitahuan dimulainya penyidikan tindak pidana imigrasi kepada penyidik polri selaku coordinator dan pengawas PPNS imigrasi sebagaimana ketentuan dalam Pasal 107 ayat (2) KUHAP dan dalam hal serah terima berkas perkara hasil penyidikan tindak pidana imigrasi dari PPNS imigrasi kepada penyidik polri selaku korwas PPNS imigrasi untuk disampaikan kepada penuntut umum sebagaimana ketentuan dalam Pasal 107 ayat (3) KUHAP dan apabila melakukan penghentian penyidikan maka memberitahukan kepada penyidik polri dari penuntut umum seperti yang ditentukan dalam Pasal 109 ayat (3) KUHAP. Penghentian penyidikan dilakukan apabila tidak teradapat cukup bukti, peristiwa tersebut bukanlah tindak pidana dan penyidikan dihentikan demi hukum seperti yang ditetukan dalam Pasal 109 ayat (2) KUHAP.

Menurut Muammar Reza selaku Analis Keimigrasian Pertama di bidang Intelijen dan Penindakan Keimigrasian pada Kantor Imigrasi Kelas I Khusus TPI Ngurah Rai, Bali mengatakan bahwa:

"penindakan yang dilakukan terhadap warga negara asing yang melakukan tindak pidana keimigrasian dengan cara memanggil, memeriksa, menggeledah, menangkap atau menahan seseorang yang disangka melakukan tindak pidana keimigrasian. Dimana laporan dari masyarakat terhadap warga negara asing yang melakukan tindak pidana sangat membantu dalam penegakan hukum keimigrasian". (Wawancara hari Jumat, tanggal 31 Januari 2020, pukul 16.30 WITA, di Ruang Penindakan Keimigrasian Kantor Imigrasi Kelas I Khusus TPI Ngurah Rai).

Salah satu kasus pelanggaran keimigrasian yang pernah terjadi terhadap orang asing di Kantor Imigrasi Kelas I Khusus TPI Ngurah Rai, Bali yaitu yang dilakukan oleh Salvarasa Krishin Pillai, berkewarganegaraan Sri Langka, yang masuk dan atau berada diwilayah Indonesia yang tidak memiliki Dokumen Perjalanan dan Visa yang sah dan masih berlaku dan dengan sengaja menggunakan Dokumen Perjalanan, tetapi di ketahui atau patut di duga bahwa Dokumen Perjalanan itu palsu atau di palsukan yang dilakukan oleh Selvarasa Krishna Pillai sebagai dimaksud dalam Pasal 119 ayat (1) atau (2) Undang-Undang Republik Indonesia Nomor 6 Tahun 2011 tentang Keimigrasian tentang Keimigrasian. Pada tanggal 16 Maret 2018 adanya informasi dari staff mascapai China Southern Airlines CZ626 yang mencurigai keaslian paspor pada saat proses check in. Terhadap terdakwa yang telah melanggar ketentuan perundang-undangan keimigrasian maka dilakukan tindakan kepadanya penahanan Rutan selanjutnya diperpanjang oleh Penuntut Umum pada Kejaksaan Negeri Tinggi Bali. Dengan sanksi pemidanaan tersebut diharapkan dapat menimbulkan efek jera dan menjadi contoh penegakan hukum keimigrasian yang tegas dengan berpegang teguh terhadap Undang-Undang Republik Indonesia Nomor 6 Tahun 2011 tentang Keimigrasian, sehingga orang asing yang berada di Bali lebih taat terhadap aturan yang berlaku di Indonesia.

Berdasarkan Penulisan pada Kantor Imigrasi Kelas I Khusus TPI Ngurah Rai, Bali, maka diperoleh rekapitulasi data jumlah tindakan projustisia periode tahun 2018 sampai dengan 2019 sebagai berikut:

Tabel 3 
Tindakan Pro-Justisia Keimigrasian Tahun 2018-2019

\begin{tabular}{|l|l|l|}
\hline No & Tahun & Jumlah Kasus \\
\hline 1. & 2018 & 8 \\
\hline 2. & 2019 & 2 \\
\hline
\end{tabular}

Sumber : Kantor Imigrasi Kelas I Khusus TPI Ngurah Rai, Bali

Data tersebut di atas yang bersumber dari Seksi Pengawasan dan Penindakan Keimigrasian Kantor Imigrasi Kelas I Khusus TPI Ngurah Rai, Bali, bahwa terhadap tindak pidana imigrasi yang terjadi di Wilayah Hukum Kantor Imigrasi Kelas I Khusus TPI Ngurah Rai, Bali. Berdasarkan uraian data tersebut di atas, dalam penegakan hukum keimigrasian yang dilaksanakan pada Kantor Imigrasi Kelas I Khusus TPI Ngurah Rai, Bali, tindakan projustisia jarang dilaksanakan, hal ini dikarenakan dirasa tidak efektif, memakan waktu yang relatif lama dalam prosesnya, dan pengalokasian anggaran yang masih belum memadai dan secara merata di semua daerah serta sumber daya manusia PPNS Keimigrasian sangat terbatas jika dibandingkan dengan penyidik Polri. Sehingga Kantor Imigrasi Kelas I Khusus TPI Ngurah Rai, Bali lebih memilih upaya hukum Non Justisia, melalui upaya hukum administrasi ataupun deportasi ke negara asalnya.

\subsection{Hambatan Pengawasan Dan Penegakan Hukum Terhadap Tindak Pidana Pelanggaran Izin Tinggal Bagi Warga Negara Asing}

Pengkajian bagian ini bertitik pangkal pada faktor pendukung yang mempengaruhi pengawasan dan penegakan hukum terhadap tindak pidana pelanggaran izin tinggal bagi Warga Negara Asing. Berdasarkan kenyataan di Kantor Imigrasi Kelas I Khusus TPI Ngurah Rai, Bali dan mengkaji dari sudut pandang kebijakan selektif. Faktor pendukung yang mempengaruhi pengawasan dan penegakan hukum terhadap tindak pidana pelanggaran izin tinggal bagi Warga Negara Asing sebagai berikut:

\section{Adanya TIMPORA (Tim Pengawasan Orang Asing)}

Direktorat Jenderal (Dirjen) Imigrasi saat ini telah melakukan berbagai langkah dan kebijakan strategis. Hal itu sebagi upaya untuk mencegah pelanggaran peraturan oleh orang asing di Indonesia. Salah satunya dengan menggalakkan Tim Pengawasan Orang Asing (TIMPORA) mulai dari tingkat pusat, provinsi, kabupaten/kota sampai tingkat kecamatan, di mana unsur Tim PORA tersebut melibatkan seluruh unsur pemerintahan. Seperti diungkapkan oleh Bapak Beny Septada selaku Kepala Seksi Pengawasan dan Penindakan Keimigrasian bahwa: "Terkait tugas Tim PORA adalah memberikan saran dan pertimbangan kepada instansi dan/atau lembaga pemerintah seperti TNI, Polri, Pemda untuk berkerja sama yang berkaitan dengan pengawasan orang asing,"8

Fungsi Tim PORA yaitu koordinasi dan pertukaran data dan informasi, pengumupalan informasi dan data keberadaan orang asing secara berjenjang, analisa dan evaluasi terhadapat data/informasi yang berkaitan dengan pelaksanaan pengawasan orang asing. Seperti diungkapkan oleh Bapak Beny Septada selaku Kepala Seksi Pengawasan dan Penindakan Keimigrasian bahwa:

${ }^{8}$ Ibid. 
"Selain itu fungsi TIM PORA adalah membuat peta pengawasan orang asing, penyelesaian permasalahan keberadaan dan kegiatan orang asing, pelaksanaan dan pengaturan hubungan serta kerja sama dalam rangka pengawasan orang asing, penyusunan rencana operasi gabungan yang bersifat khusus atau insidentil". 9

\section{Adanya APAPOA (Aplikasi Pelaporan Orang Asing)}

Selain itu dalam rangka mengefektifkan pengawasan orang asing, Dirjen Imigrasi juga membuat Aplikasi Pelaporan Orang Asing (APOA), hal itu dlakukan guna untuk mengawasi orang asing yang bertempat tinggal atau menginap di suatu tempat penginapan. APAPOA (Aplikasi Pelaporan Orang Asing) adalah penggunaan aplikasi untuk pelaporan orang asing yang berada di wilayah Republik Indonesia sebagai contoh misalnya orang asing yang menginap di hotel-hotel. Seperti diungkapkan oleh Muammar Reza selaku Analis Keimigrasian Pertama Bidang Intelijen dan Penindakan Keimigrasian bahwa:

"Jadi setiap orang asing yang datang ke Indonesia setelah melalui proses pemeriksaan keimigrasian di tempat pemeriksaan keimigrasian, di paspornya akan diberikan stiker yang berisi barcode yang berisi data keimigrasian orang asing tersebut, ini dikaitkan dengan aturan penegakan Undang-Undang Nomor 6 Tahun 2011 tentang Keimigrasian Pasal 72 (2) yang mewajibkan pemilik atau pengurus tempat penginapan wajib memberikan data mengenai orang asing yang menginap di tempat penginapannya,"10

Berdasarkan pada pendapat diatas dan melihat pada kenyataan bahwa dengan APOA ini akan guna mempermudah pemilik atau pengurus rumah penginapan melaporkan secara online orang asing yang menginap ditempatnya, dan Dirjen Imigrasi pun memanfaatkan teknologi $\mathrm{QR}$ Code dalam rangka peningkatan pengawasan orang asing. Melalui aplikasi khusus pembaca QR Code, petugas Imigrasi dapat menampilkan data yang diperlukan di layar smartphone petugas dan mengirimkan posisi lokasi pemindaian, sehingga data lokasi tersebut dapat digunakan untuk menghitung keberadaan orang asing dan memantau pergerakannya.

\section{SSO (Single Sign On)}

Ditjen Imigrasi menyederhanakan pengawasan saat ini melalui layanan SSO (Single Sign On). Sistem Keimigrasian ini dipergunakan oleh petugas khusus yang memiliki login yg sampai ke direktorat. Seperti diungkapkan oleh Muammar Reza, selaku Analis Keimigrasian Pertama Bidang Intelijen dan Penindakan Keimigrasian bahwa: "Disana petugas bisa memasukkan nama, no paspor, selanjutnya akan terlihat data lengkap warga negara asing berupa berapa kali datang ke Bali dan nama penjamin dll. Ini memudahkan dalam penyelidikan awal."11

Berdasarkan pada pendapat diatas dan melihat pada kenyataan bahwa tim pengawasan Kantor Imigrasi Kelas I Khusus Ngurah Rai, Bali memiliki grup whatapp masing-masing yang mempermudah dalam pengawasan. Ketika melaksanakan

\footnotetext{
${ }^{9} \mathrm{Ibid}$.

${ }^{10}$ Muammar Reza, Analis Keimigrasian Pertama Bidang Intelijen dan Penindakan Keimigrasian, Wawancara, Ruang Penindakan Keimigrasian Kantor Imigrasi Kelas I Khusus TPI Ngurah Rai, 31 Januari 2020, pukul 16.30 WITA.

${ }^{11}$ Ibid.
} 
penyelidikan maka semua informasi warga Negara asing yang diduga melakukan pelanggaran bisa dimuat secara tepat dan cepat pada waktu saat itu juga. Dalam whatapps ketua tim menentukan job desk masing-masing petugas dari proses intelijen sampai penangkapan warga Negara asing. Adanya tim BAP dari tim penindakan yg mendapatkan bukti awal dari Laporan Pengawasan (LAPWAS) dalam tim pengawasan.

Berdasarkan kajian diatas dengan melihat suatu pola karakter yang dikaitkan dengan kebijakan pengawasan dan penegakan hukum terhadap tindak pidana pelanggaran izin tinggal bagi Warga Negara Asing di Kantor Imigrasi Kelas I Khusus Ngurah Rai, Bali ditemukan adanya saling mendukung antar instansi dan adanya saling ketergantungan untuk saling mendukung dalam proses penegakan hukum berdasarkan prinsip kebijakan selektif dimana hanya orang asing yang dapat memberikan manfaat bagi kesejahteraan rakyat, bangsa, dan negara, tidak membahayakan keamanan dan ketertiban, serta tidak bermusuhan baik terhadap rakyat yang dapat masuk dan keluar wilayah Indonesia.

Pengkajian bagian ini bertitik pangkal pada faktor penghambat yang mempengaruhi pengawasan dan penegakan hukum terhadap tindak pidana pelanggaran izin tinggal bagi Warga Negara Asing. Faktor penghambat yang mempengaruhi pengawasan dan penegakan hukum terhadap tindak pidana pelanggaran izin tinggal bagi Warga Negara Asing sebagai berikut:

\section{Sumber Daya Manusia}

Berdasarkan Penulisan dan analisis didapati bahwa hambatan dalam penegakan hukum terhadap tindak pidana penyalahgunaan izin tinggal keimigrasian di Kantor Imigrasi Kelas I Khusus Ngurah Rai, Bali adalah jumlah petugas Imigrasi yang melakukan pengawasan serta monitoring terhadap keberadaan orang asing dirasa kurang, dan kurangnya PPNS Imigrasi yang menguasai bahasa asing selain bahasa Inggris, terbatasnya jumlah sarana penunjang operasional dan masyarakat Lampung yang bersifat non kooperatif dimana laporan ataupun pengaduan dari masyarakat mengenai keberadaan atau kegiatan orang asing yang ada disekitarnya masih sangat sedikit.

Seperti diungkapkan oleh Muammar Reza selaku Analis Keimigrasian Pertama Bidang Intelijen dan Penindakan Keimigrasian bahwa:

“Tingginya intensitas warga Negara asing di Bali yang juga berbarengan dengan dengan tingkat pelanggaran yang tinggi. Saat ini masih kekurangan penyidik Imigrasi dari segi kualitas. Untuk sumber daya manusia kami memang ada, walau sedikit, tapi yang ada belum qualified. Penyidik Imigrasi masih terus belajar kepada kepolisian mengenai tata cara penyidikan yang baik dan benar. Selain itu SDM di Kantor Imigrasi Kelas I Khusus Ngurah Rai, Bali juga tidak semua paham proses penyidikan. Indikator lainnya yakni tidak banyak SDM di pengawasan dan penindakan keimigrasian (wasdakim) adalah seorang PPNS karena untuk perkara proju penyidikan dilakukan oleh PPNS" ${ }^{12}$

Berdasarkan pada pendapat diatas dan melihat pada kenyataan bahwa kurangnya PPNS Imigrasi yang menguasai bahasa asing selain bahasa Inggris. Padahal umumnya

12 Ibid. 
orang asing yang diperiksa tidak menguasai bahasa Inggris. Sehingga untuk melakukan pemeriksaan terhadap kasus yang sedang ditangani oleh PPNS Imigrasi terhadap orang asing dari negara tertentu harus memerlukan ahli bahasa atau penterjemah. Hal ini menyulitkan petugas dalam melakukan pemeriksaan. Misalnya saja dalam pemeriksaan WNA asal Afganistan, Cina, Jepang, Mesir, atau negaranegara lain yang tidak terbiasa dengan bahasa Inggris.

\section{Fasilitas Penunjang}

Setiap pelaksaan kegiatan pasti memiliki hambatan-hambatan walaupun telah direncanakan dengan baik, begitu juga penegakan hukum terhadap tindak pidana penyalahgunaan izin tinggal keimigrasian memiliki hambatan-hambatan. Seperti diungkapkan oleh Muammar Reza selaku Analis Keimigrasian Pertama Bidang Intelijen dan Penindakan Keimigrasian bahwa: "ketersediaan fasilitas penunjang operasional seperti kendaraan, masih minim". ${ }^{13}$

Berdasarkan pada pendapat diatas dan melihat pada kenyataan bahwa fasilitas penunjang kerja aparat petugas Imigrasi yang kurang seperti kendaraan operasional dapat ditingkatkan lagi. Dengan adanya fasilitas yang menunjang dapat membantu dalam pengawasan dan penegakan hukum bagi warga Negara asing yang diduga melakukan pelanggaran

3. Waktu yang relatif lama dalam menyelesaikan berkas perkara.

Setiap perkara keimigrasian biasanya membutuhkan waktu minimal 3 bulan untuk menyelesaikan perkara tersebut. Berdasarkan hasil wawancara selama Penulisan pada Kantor Imigrasi Kelas I Khusus Ngurah Rai, Bali dengan Muammar Reza selaku Analis Keimigrasian Pertama Bidang Intelijen dan Penindakan Keimigrasian mengatakan bahwa "keimigrasian dalam hal implementasinya secara operasional telah memenuhi tuntutan perubahan zaman reformasi. Begitu juga dalam sistem hukum, dimana dalam pelaksanaannya telah sesuai dengan prosedur yang sederhana dengan prinsip public accountability yang berlandaskan pada azas transparansi (keterbukaan)" ${ }^{14}$

Berdasarkan pada pendapat diatas dan melihat pada kenyataan bahwa penegakan hukum keimigrasian tidak berjalan sebagaimana diharapkan tanpa ada Sumber Daya Manusia yang sesuai, sistem hukum yang jelas dan sarana yang memadai, tanpa adanya aparat penegakan hukum yang bermoral dan berintegrasi tinggi maka tujuan dari pembentukan Undang-undang Keimigrasian yang ada tidak akan tercapai secara optimal.

Tujuan akhir dari penegakan hukum terhadap tindak pidana penyalahgunaan izin tinggal keimigrasian adalah adanya ketaatan hukum dan keteraturan bagi warga negara asing yang keluar masuk wilayah Indonesia. Untuk mencapai hal tersebut sangat penting sekali bagaimana peran Imigrasi dalam menjadikan warga negara asing yang berada di Indonesia patuh terhadap hukum yang berlaku. Setiap pelaksaan kegiatan pasti memiliki hambatan-hambatam walaupun telah direncanakan dengan baik, begitu juga penegakan hukum terhadap tindak pidana penyalahgunaan izin tinggal keimigrasian memiliki hambatan-hambatan.

${ }^{13}$ Ibid.

14 Ibid. 


\section{Kesimpulan}

Proses penegakan hukum terhadap tindak pidana pelanggaran izin tinggal bagi Warga Negara Asing di Kantor Imigrasi Kelas I Khusus TPI Ngurah Rai, Bali yakni dengan Tindakan Projustisia dan Tindakan Administratif Keimigrasian berupa deportasi. Dalam proses penahan warga negara asing sebelum dilakukan tindakan deportasi diberikan hak-hak sesuai dengan kebutuhan pokok sehari-harinya.

Hambatan dalam pengawasan dan penegakan hukum terhadap tindak pidana pelanggaran izin tinggal bagi Warga Negara Asing di Kantor Imigrasi Kelas I Khusus TPI Ngurah Rai, Bali yakni :

1. Faktor pendukung yang mempengaruhi pengawasan dan penegakkan hukum terhadap Tindak Pidana pelanggaran Izin Tinggal bagi warga negara asing:
a. Adanya TIMPORA (Tim Pengawasan Orang Asing);
b. Adanya APAPOA (Aplikasi Pelaporan Orang Asing);
c. SSO (Single Sign On).

2. Faktor penghambat yang mempengaruhi pengawasan dan penegakkan hukum terhadap Tindak Pidana pelanggaran Izin Tinggal bagi warga negara asing:
a. SDM (Sumber Daya Manusia);
b. Fasilitas Penunjang;
c. Waktu yang relatif lama dalam menyelesaikan berkas perkara.

\section{Daftar Pustaka}

Buku

Atmadja, I., Dewa Gede. Filsafat Hukum. Dimensi Tematis dan Historis. Malang: Setara Press, (2013).

Putra, I. B. W. Filsafat Ilmu: Filsafat Ilmu Hukum. Denpasar: Udayana University Press, (2015).

\section{Jurnal}

Dharmawan, N. K. S. Keberadaan Pemegang Saham dalam Rups dengan Sistem Teleconference Terkait Jaringan Bermasalah dalam Perspektif Cyber Law. Jurnal Magister Hukum Udayana (Udayana Master Law Journal), 4 no. 1, (2015). 190-202. https://doi.org/10.24843/JMHU.2015.v04.i01.p15.

Disemadi, Hari Sutra; Prananingtyas, Paramita. Perlindungan Hukum Terhadap Nasabah Perbankan Pengguna CRM (Cash Recycling Machine). Jurnal Magister Hukum Udayana (Udayana Master Law Journal, [S.l.], v. 8, n. 3, p. 286402,https:// doi.org/10.24843/JMHU.2019.v08.i03.p07

Resen, M. G. S. K. Inovasi Daerah (Refleksi dan Pengaturan Inovasi Daerah di Indonesia). Jurnal Magister Hukum Udayana (Udayana Master Law Journal), 4 no. 4, (2015). 680-687. https:// doi.org/10.24843/JMHU.2015.v04.i04.p07.

Siki, Renhat M. Kajian Karakteristik Bentuk dan Isi Perda Tentang Bendega Jurnal Magister Hukum Udayana (Udayana Master Law Journal), 7 no. 3, (2018), 375-385. https://doi.org/10.24843/JMHU.2018.v07.i03.p08. 
Susila, I. N. A. Pengaturan Kawasan Suci Pantai Dalam Penyediaan Sarana Wisata Tirta Di Provinsi Bali. Jurnal Magister Hukum Udayana (Udayana Master Law $\begin{array}{lllll}\text { Journal), } & 6 & \text { no. } & \text { (2017), } & \text { 478-488. }\end{array}$ https://doi.org/10.24843/JMHU.2017.v06.i04.p06.

$\underline{\text { Tesis atau Disertasi }}$

Atmaja, G. M. W. Politik Pluralisme Hukum Dalam Pengakuan Kesatuan Masyarakat Hukum Adat Dengan Peraturan Daerah. Disertasi Doktor. PDIH Fakultas Hukum Universitas Brawijaya, Malang, (2012).

Wawancara

Beny Septada, Kepala Seksi Pengawasan dan Penindakan Keimigrasian, Wawancara, Ruang Office Imigrasi TPI Ngurah Rai, 14 Februari 2020, pukul 15.00 WITA.

Muammar Reza, Analis Keimigrasian Pertama Bidang Intelijen dan Penindakan Keimigrasian, Wawancara, Ruang Penindakan Keimigrasian Kantor Imigrasi Kelas I Khusus TPI Ngurah Rai, 31 Januari 2020, pukul 16.30 WITA. 